\title{
FACTORS THAT CAUSE OF LAND CONVERSION TO THE INCREASING OF FLOODING RISK IN MANGGALA SUB- DISTRICT, MAKASSAR
}

\author{
Adhe Reza Rachmat*, Adjie Pamungkas**, Rimadewi Suprihardjo** \\ *) Master Student, Department of Architecture, Faculty of Civil Engineering and \\ Planning, Institut Teknologi Sepuluh Nopember, Indonesia \\ **) Lecturer, Department of Architecture, Faculty of Civil Engineering and \\ Planning, Institut Teknologi Sepuluh Nopember, Indonesia \\ e-mail: derezara@gmail.com
}

\begin{abstract}
Flooding that occurred in Manggala Sub-district gave negative impact to the community in the form of material loss and disruption of community activities. This condition was caused by vulnerable landscapes and inadequate drainage systems. Besides, it was caused by the high rate of construction growth phenomenon. The phenomenon led to the conversion of agricultural land and green open space into residential. Consequently, it emerged insistence on drainage and infiltration capacity of the soil to the surface water runoff, thus increasing the risk of flooding in Manggala Sub-District. Therefore, this study aimed to determine the factors that cause of land conversion triggering an impact in increasing of flooding risk in Manggala Subdistrict. This article is a part of research on the formulation the concept of controlling spatial utilization in improving the resilience of city against flooding in the Manggala Sub-District, Makassar. Through Content Analysis technique, the variables that cause of land conversion to the increasing of flooding risk were found. The results showed that there were 4 (four) factors. That causes of land conversion in Manggala Sub-district: the lack of planning and law enforcement related to spatial planning; high demand for housing; the low price of open land; the uneven and partial of infrastructure's supply.
\end{abstract}

Keywords: land conversion, flooding risk, content analysis

\section{ABSTRAK}

Banjir di Kecamatan Manggala menimbulkan dampak negatif terhadap masyarakat dalam bentuk evakuasi dan kerugian material. Banjir tersebut selain disebabkan oleh kondisi rona alam yang rentan dan sistem drainase yang belum memadai, namun juga disebabkan oleh fenomena laju pertumbuhan pembangunan yang tinggi. Fenomena tersebut menyebabkan adanya konversi lahan pertanian dan ruang terbuka hijau menjadi permukiman. Kondisi tersebut menyebabkan desakan kepada 
kapasitas drainase dan laju infiltrasi tanah terhadap limpasan air permukaan, sehingga meningkatkan risiko bencana banjir di Kecamatan Manggala. Oleh karena itu, diperlukan kajian mengenai faktor penyebab perubahan penggunaan lahan yang memicu dampak dalam meningkatkan risiko banjir di Kecamatan Manggala. Artikel ini sendiri merupakan bagian dari penelitian mengenai konsep pengendalian pemanfaatan ruang dalam meningkatkan ketahanan kota terhadap bencana banjir di Kecamatan Manggala Kota Makassar. Dalam penelitian ini dilakukan analisis melalui content analysis untuk mengetahui faktor penyebab perubahan penggunaan lahan sehingga memicu dampak dalam meningkatkan risiko banjir. Hasil penelitian menghasilkan 4 faktor penyebab perubahan penggunaan lahan di Kecamatan Manggala. Faktor penyebab tersebut antara lain: lemahnya perencanaan dan penegakan hukum terkait penataan ruang; permintaan penduduk akan rumah tergolong tinggi; murahnya harga lahan terbuka; dan penyediaan infrastruktur yang belum merata dan parsial.

Kata kunci: perubahan penggunaan lahan, risiko banjir, content analysis

\section{INTRODUCTION}

Flooding is one of the natural phenomena that occur as a result of high rainfall intensity and caused excess water not absorbed by the drainage system. This condition may result inundation that could harm community (Harjadi, et al, 2007). As a result of intense rainfall and significant dynamic by the high rate of evaporation of sea water, this condition may result a puddle which can harm the community (Rusbiantoro, 2008).

According to Rencana Tata Ruang Wilayah Kota Makassar (Spatial Planning of Makassar City) 2006-2015, Makassar include to a flood-prone areas category because it has a natural hue conditions vulnerable to flooding, such as the sloping topography and large river crossings (Tallo and Jeneberang) (BPBD Kota Makassar, 2014). Moreover, the condition of the drainage system was not adequate, causing the risk of flooding increased, especially in the eastern region of Makassar (Dinas Tata Ruang dan Permukiman Provinsi Sulawesi Selatan, 2011). Based on the flooding events last 5 years, the region has always affected by floods, especially Manggala Sub-district which every year suffered floods giving direct impacts to the community (BPBD Kota Makassar, 2014).

Flood in Manggala Sub-district has resulted a lot of harm such as the evacuation of people and loss materials. Those were shown on the report of floods in 2013 that flood resulted in 4555 inhabitants were evacuated and 2461 houses were flooded. In addition to its natural hue conditions of vulnerable areas such as the formation of the basin area and drainage systems are inadequate, the condition due to the development of high growth phenomenon that can be seen in the rate of construction of buildings increased by $\pm 17.3 \%$ in the last 5 years (BPBD Kota Makassar, 2014).

The high rate of development growth due to the determination of this region as an integrated residential areas in RTRW Makassar 2006-2015. Therefore, the land conversions every year are affected by the activities and population growth in the 
region (DTRB Makassar, 2012). The determination also led to the insistence of land conversion of fields and green open spaces into residential in large numbers. In 2011 there was land conversion of 26 hectares area of fields into constructed land(BPS Kota Makassar, 2012). Widespread area caused exhortation to the drainage capacity and infiltration rate of the soil surface water runoff.

Therefore, to formulate flooding mitigation especially in controlling the land use, required a study to identify factors that cause of land conversion triggering the effects that increase flooding risk in Manggala Sub-district. This study based on theories of land use changes and the risk of flooding, as a guide and measuring tools for the exploration of empirical conditions related to land conversion phenomenon to the increasing of flooding risk in the research area.

\section{THEORY / RESEARCH METHODS}

\section{Methods of Data Collection}

Methods of data collection in this study were divided into two types, namely the method of collecting primary and secondary data. Primary data collection conducted by observation and in-depth interview to stakeholders who have been determined through stakeholders analysis, consists of three groups that have been encoded for the sake of content analysis (Table 1).

Table 1. Stakeholders In-depth Interview

\begin{tabular}{ccc}
\hline No & Code & Stakeholders \\
\hline 1 & Governance Group \\
& G1 & Disaster Management Agency of Makassar \\
& G2 & Spatial Planning and Building Agency of Makassar \\
& Private Sector Group \\
& P1 & Perumnas Antang Housing Developer \\
& P2 & Private Housing Developer \\
& Civil Society Group \\
& C1 & Communication Forum of Manggala Sub-District Community \\
& C2 & Empowerment Agency \\
& & Tamangapa Farmer Group \\
\hline
\end{tabular}

While secondary data collection conducted by literature survey as well as institutional survey to get a general overview of Manggala Sub-district, Makassar, particularly the conditions of land use and flood events (Figure 1). 


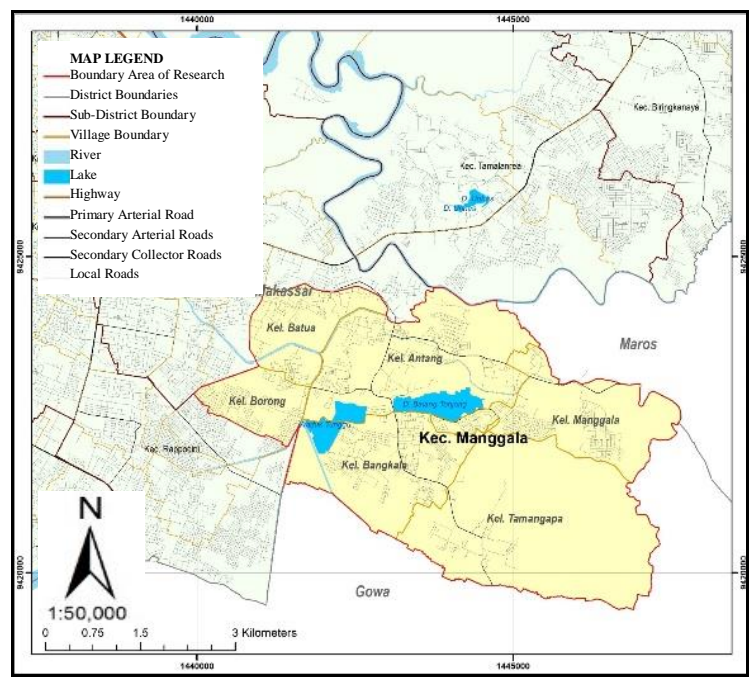

Figure 1. The Orientation Map Area Source: author's documentation

\section{Method of Analysis}

This study uses the variables generated through literature review based on theories about land conversion. The variable represented the parameter to identify the factors causing land conversion in the study area, can be seen in Table 2. Content Analysis is used as an analysis tool to identify the cause of land conversion. Content analysis is an exploration techniques to make inferences that can be emulated correctly and still consider to the context (Krippendorff, 1993).

Table 2. Variables Cause of Land Conversion

\begin{tabular}{ccl}
\hline No & Code & \multicolumn{1}{c}{ Cause of Land Conversion } \\
\hline 1 & PE1 & Topographic Conditions \\
2 & PE2 & Population Growth \\
3 & PE3 & Economic Growth in the Region \\
4 & PE4 & Income Level \\
5 & PE5 & Land Prices \\
6 & PE6 & Government Policy \\
7 & PE7 & Law Enforcement \\
8 & PE8 & The Availability of Basic Infrastructure \\
9 & PE9 & Distance to the Service Centers \\
\hline
\end{tabular}

These variables are materials to be explored through in-depth interviews with selected stakeholders. Exploration results will be transformed into a transcript of the interview which will be analyzed further. In conducting content analysis process, using the unit of analysis in the form of units of a sentence, so that each unit of a sentence which has the purpose that leads to the explanation of the variables above, 
will be encoded according to the variables indicated. The coding process uses semantic content analysis which classifies signs based on owned meaning and simplified in the tabulation using assertion analysis to show the frequency influential indications of each variable on caused land conversions The results of coding and simplification are used to understand the data by looking back at the conversational elements namely style of speech, to see the significance of the influential variables. The end result of this analysis is the narrating process in the form of abstraction results. Abstraction is done by transforming the variables causes into influential factors on the cause of land conversion to the increasing of flooding risk in Manggala Sub-district, Makassar. See the following Figure 2 to get more details about the stages of Content Analysis.

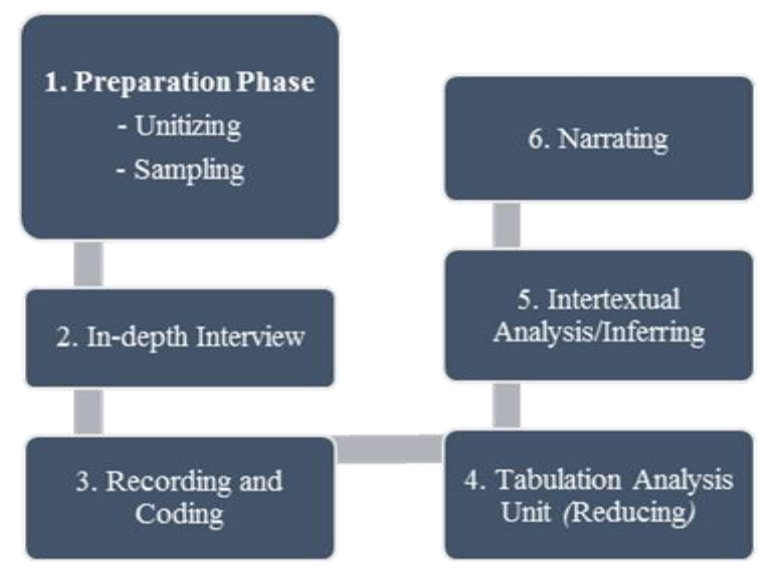

Figure 2.Content Analysis Process Flow Source: processed from Krippendorff, 2004

\section{RESULTS AND DISCUSSIONS}

Analysis process and discussion conducted refers to Figure 2, results in the preparation stage, the interview, and the making of transcripts is a preliminary stage. As for the steps described in the results and discussion is limited to the coding stage until narrating.

\section{Results of Coding Data}

Coding process conducted on transcript of semi-structured interviews to selected stakeholders and has been transformed into the transcript. In discovering the inference of variable related to the factors causing land use changes conducted by looking at each unit of analysis on transcripts. Unit of analysis which has the effect inference to certain variable be encoded by the variable indicated. Here's Figure 3 an example of the coding process in this study. 
$\mathrm{P}$ : Is the population growth here is high, sir? What its influence on the phenomenon of land conversion?

P1 : Yes, this region has been already quite dense. The effects related to housing needs of society. The more the number the population, the demand for houses will be even greater, so that the effort to build on a land will be increased, although the form of the land firstly was a fields or swamp.

Figure 3. Quote of Finding Code from Stakeholder 4 (P1) Source: In-depth interview, 2015

Based on the quote above, it is known that the stakeholder 6 indicates an inference related the effect of high population growth in the research area as one of the things that led to land use changes. It is shown from the correlation between the numbers of residents with housing needs, thus increasing the occupation of land into settlements. Therefore, the unit of analysis in these quotations is coded by PE2.4 because it has indicated an inference of the effect of population growth variable (PE2) by sequence of repetition to 4 on the variables in the entire transcript of the interview.

\section{Results of Reducing Data}

The next stage was the reducing data in the form of tabulation unit of analysis with the same inference to a variable caused land conversion. It would indicated that variable could be said to be influential or otherwise. Furthermore it will investigate the possibility of the main variables caused land conversion in Manggala Sub-district. Here's Table 3 of the results tabulation unit of analysis associated causing land conversion.

Table 3. Results of Tabulation Unit of Analysis Associated Causing Land Conversion

\begin{tabular}{clcccc}
\hline No & $\begin{array}{c}\text { Variables that Cause Land } \\
\text { Conversion }\end{array}$ & $\begin{array}{c}\text { Number of Iterations } \\
\text { Analysis Unit }\end{array}$ & \multicolumn{2}{c}{$\begin{array}{c}\text { Composition of Stake- } \\
\text { holders Agreement }\end{array}$} \\
\cline { 3 - 6 } & & Influential & $\begin{array}{c}\text { Not Influen- } \\
\text { tial }\end{array}$ & $\begin{array}{c}\text { Influential } \\
\text { Not Influen- } \\
\text { tial }\end{array}$ \\
\hline 1. & Topographic Conditions (PE1) & 17 & 1 & 5 & 1 \\
2. & Population Growth (PE2) & 8 & 0 & 6 & 0 \\
3. & $\begin{array}{l}\text { Economic Growth in the Re- } \\
\text { gion (PE3) }\end{array}$ & 5 & 1 & 5 & 1 \\
4. & Income Level (PE4) & 9 & 0 & 6 & 0 \\
5. & Land Prices (PE5) & 11 & 0 & 6 & 0 \\
6. & Government Policy (PE6) & 14 & 0 & 6 & 0 \\
7. & Law Enforcement (PE7) & 49 & 0 & 6 & 0 \\
8. & The Availability of Basic In- & 8 & 3 & 4 & 2 \\
frastructure (PE8) & Distance to the Service Center & 7 & 0 & 6 & 0 \\
9. & (PE9) & & & & \\
\hline
\end{tabular}


The table above shows that all variables is indicated to influential variable by the majority of stakeholders. However, there are several variables that indicated has no effect by 1 to 2 stakeholders, such as topography, economic growth in the region, and the availability of basic infrastructure. Nevertheless, the majority of all these variables indicated to be influential.

In addition to an indication of such influence, there are tabulation unit of analysis with the same inference, which known that law enforcement variable is most often frequent repetition entire transcript of the interview inference in this study. It represents that the variable is most dominant influence the land conversions in Manggala Sub-district.

\section{Results of Inferring Data}

Stage of inferring data aimed to understanding the stages of data aims to find a significant effect of a variable according to a statement stated by each stakeholders. Then intertextual analysis of the revelation of each stakeholders is conducted resulting in the conclusion of the analysis. In determining the significance, it considers the elements such conversational style of speaking from the stakeholders, such as tone of voice. Thus it can be seen the significance of the effect of a variable that influence land conversions in Manggala Sub-district. Figure 4 is an example of quotes in the transcripts related to elements of conversation.

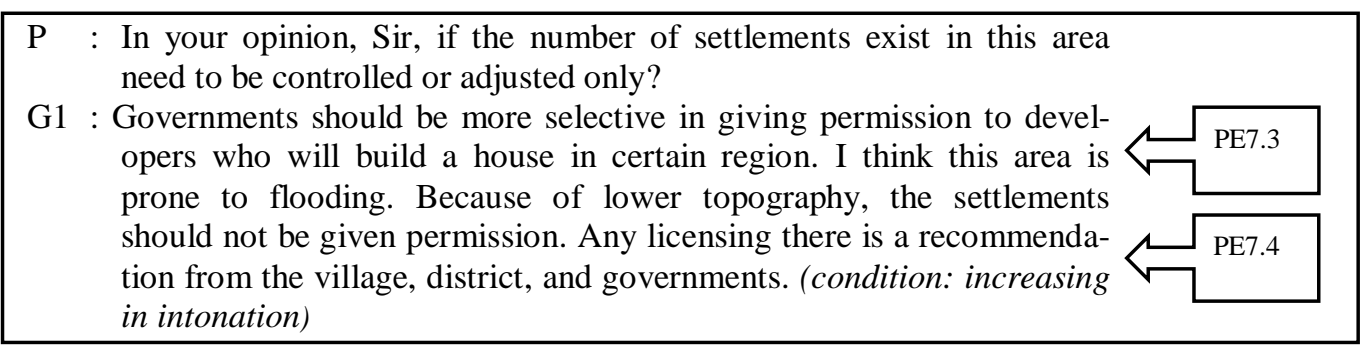

Figure 4. Quote of Finding Code from Stakeholder 1 (G1) Source: In-depth interview, 2015

Based on the quote above, there was an increasing in intonation of stakeholder 1 (G1) stated indications of influence of law enforcement variable (PE7). It represents that the influence of law enforcement variables as cause of land use changes in Manggala Sub-district is quite large. It is also known from the statements expressed by stakeholder 1 (G1), that weak law enforcement led to the phenomenon of the construction of the building is not suitable for a residential area. Beside these variables, there are others variables which indicated very influential. Table 4 below is the result of the process of understanding the data in determining the significance of the effect of a variable. 
Table 4. Indications of the Significance Influence of Cause Land Conversion Variables

\begin{tabular}{|c|c|c|c|c|c|c|c|}
\hline \multirow[t]{2}{*}{ Num. } & \multirow{2}{*}{$\begin{array}{c}\text { Variables that Cause Land Con- } \\
\text { versions }\end{array}$} & \multicolumn{6}{|c|}{$\begin{array}{l}\text { Indications of Significance the Influence } \\
\text { of Variables According to Stakeholders }\end{array}$} \\
\hline & & G1 & G2 & P1 & $\mathbf{P 2}$ & C1 & $\mathrm{C2}$ \\
\hline 1. & Topographic Conditions (PE1) & SP & $\mathrm{P}$ & PP & TPP & $\mathrm{P}$ & $\mathrm{P}$ \\
\hline 2. & Population Growth (PE2) & SP & $\mathrm{P}$ & $\mathrm{P}$ & $\mathrm{P}$ & $\mathrm{P}$ & SP \\
\hline 3. & $\begin{array}{l}\text { Economic Growth in the Region } \\
\text { (PE3) }\end{array}$ & $\mathrm{P}$ & $\mathrm{TP}$ & $\mathrm{P}$ & $\mathrm{P}$ & $\mathrm{P}$ & $\mathrm{P}$ \\
\hline 4. & Income Level (PE4) & $\mathrm{P}$ & $\mathrm{P}$ & $\mathrm{P}$ & $\mathrm{P}$ & $\mathrm{P}$ & $\mathrm{P}$ \\
\hline 5. & Land Prices (PE5) & SP & $\mathrm{P}$ & $\mathrm{P}$ & $\mathrm{P}$ & $\mathrm{P}$ & $\mathrm{P}$ \\
\hline 6. & Government Policy (PE6) & SP & SP & $\mathrm{P}$ & $\mathrm{P}$ & $\mathrm{P}$ & $\mathrm{P}$ \\
\hline 7. & Law Enforcement (PE7) & SP & SP & SP & $\mathrm{P}$ & SP & SP \\
\hline 8. & $\begin{array}{l}\text { The Availability of Basic Infra- } \\
\text { structure (PE8) }\end{array}$ & TPP & TP & $\mathrm{P}$ & $\mathrm{P}$ & $P$ & $\mathrm{P}$ \\
\hline 9. & $\begin{array}{l}\text { Distance to the Service Center } \\
\text { (PE9) }\end{array}$ & $P$ & SP & $\mathrm{P}$ & $\mathrm{P}$ & $\mathrm{P}$ & $\mathrm{P}$ \\
\hline
\end{tabular}

Source: results of analysis, 2015

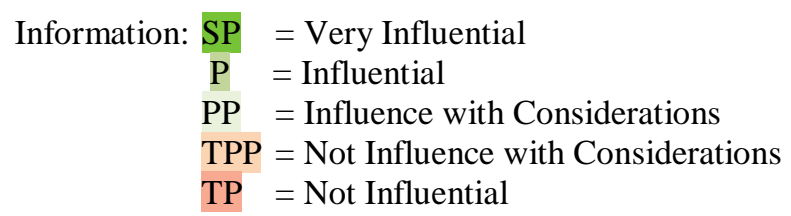

Table 4 shows that most of the stakeholders (5 of 6) states law enforcement variable as a very influential variable. In addition, there are two stakeholders' states that variable population growth, government policies, there are as a very influential variable. While the topography and distances with service center indicated as a very influential variable by one stakeholder. The rest is only considered influential.

However, in concluding the results need to conducted intertextual analysis to know the consensus influence of a variable that cause land conversion. Textual analysis conducted by inferring each conclusion of statement purpose of each stakeholder in each group, so that generate understanding of each group of stakeholders towards influence of a variable. Then, it continued by inferring each conclusion of understanding of each group, resulting conclusions related to the effect of a variable that caused land conversion in Manggala Sub-district. Table 5 is an example of the process of intertextual analysis in determining the conclusion understanding of the influence of a variable.

The results of intertextual analysis example show that population growth (PE2) is obviously influence due to population growth will be correlated with the demand for residential land, so that the change in land use for settlement becomes unstoppable. Then, adjusting the results of inferring, it is known that all variables are influence as a cause of land conversions in Manggala Sub-district with the most dominant variable is law enforcement which 5 of 6 stakeholders stated this variable 
very influence. Figure 5 shows the sequence of related variables influence the causes of land conversion in Manggala Sub-district.

Table 5. Example of Intertextual Analysis Results of Population Growth Variable (PE2) as Cause of Land Conversion

\begin{tabular}{|c|c|}
\hline Results of Inferring of Each Group of Stakeholders & $\begin{array}{l}\text { Conclusion of Inferring } \\
\text { the Influence of Variable }\end{array}$ \\
\hline $\begin{array}{l}\text { GOVERNANCE } \\
\text { According to opinion of two stakeholder of governance, popula- } \\
\text { tion growth will be closely related to the need for housing, so } \\
\text { the need for land for housing also increased. Finally, It is trigger } \\
\text { land conversion which were dominated by fields firstly to be } \\
\text { residential in Manggala Sub-district. } \\
\text { PRIVATE SECTOR } \\
\text { Not much differs from the opinion of government stakeholders, } \\
\text { the private sector is also associates population growth with sup- } \\
\text { ply and demand for housing, so there is an attempt for developer } \\
\text { to provide them, although the change of land use of wetland / } \\
\text { marsh. } \\
\text { CIVIL SOCIETY } \\
\text { Society give an opinion that the number of residents in the } \\
\text { Manggala Sub-district is already crowded, either alone or popu- } \\
\text { lation growth from the entry into this growing region, both its } \\
\text { own population growth and migrant that come to this region is } \\
\text { greater. As a results of this condition, there are some land have } \\
\text { been plotted into land for residential or there are some housing } \\
\text { developers who develop in almost every type of land (fields, } \\
\text { shrubs, and gardens) }\end{array}$ & $\begin{array}{l}\text { Based on the results of } \\
\text { inferring the whole group } \\
\text { of stakeholders it indicate } \\
\text { population growth as a } \\
\text { variable that causes land } \\
\text { conversion, due to popu- } \\
\text { lation growth will be cor- } \\
\text { related with the demand } \\
\text { for residential land, so } \\
\text { that the land conversion } \\
\text { for settlement becomes } \\
\text { unstoppable. }\end{array}$ \\
\hline
\end{tabular}
Source: analysis results, 2015

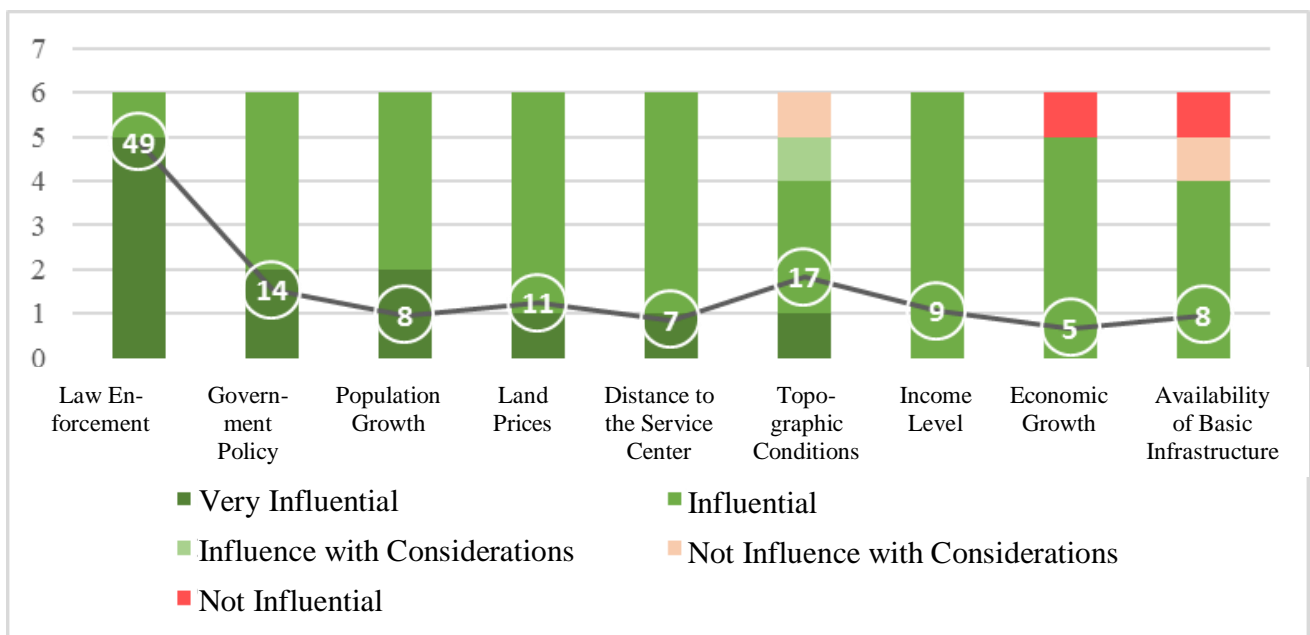

Figure 5. The Sequence of Related Variables Influence the Causes Land Conversions in Manggala Sub-District

Source: content analysis, 2015 Note: Line Chart Showing the Frequency Analysis Unit (Influence) of Each Variable. 


\section{Narrating and Establishment of Factors}

The variables that have been concluded as influential variables on the previous stage, then it reanalyzed to be formed into a factor, where each factor explained by one or more variables that have the same characteristics. For more details about the factors that cause land conversion that influence in Manggala Sub-district can be explained as follows (Figure 6).

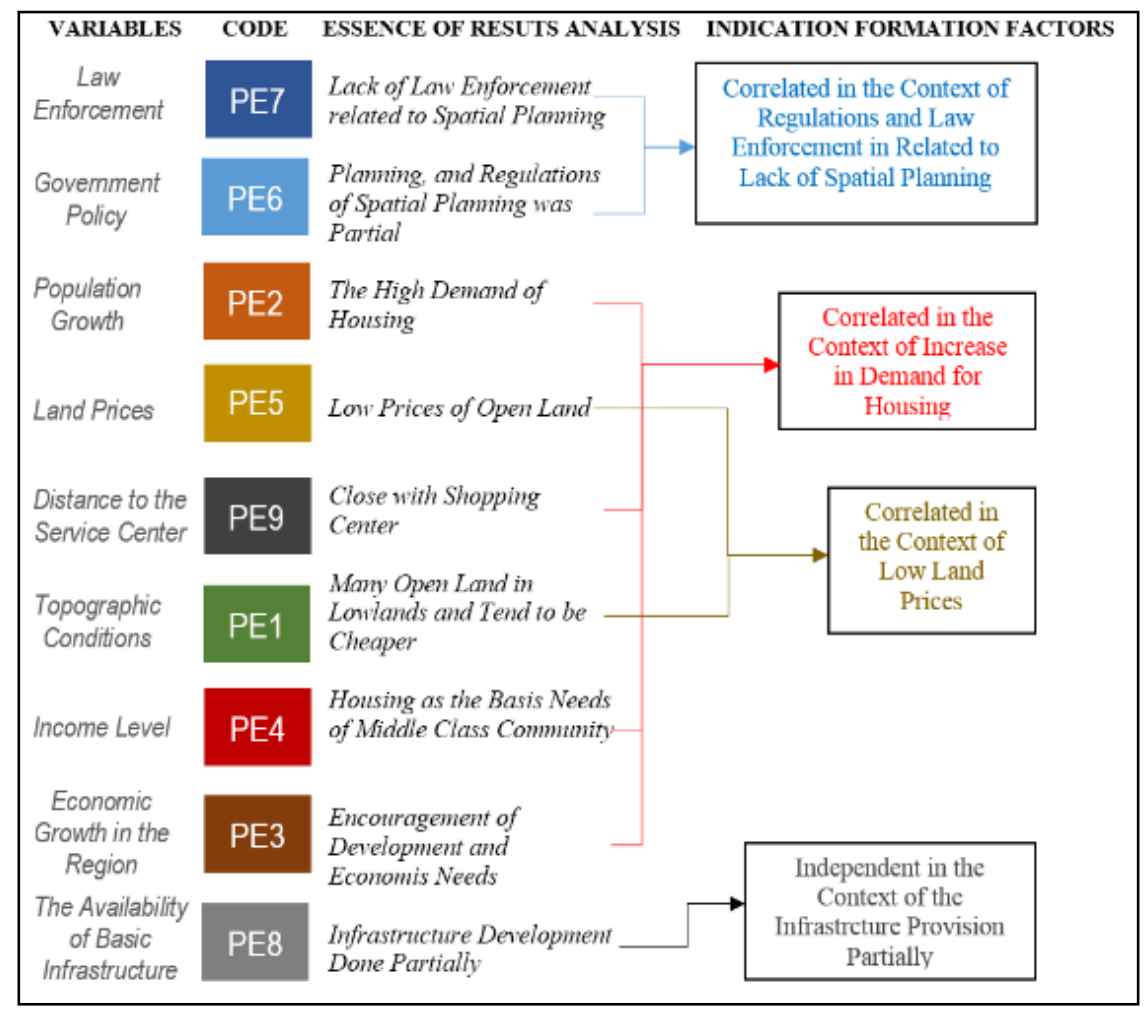

Figure 6. Formation Process of Factors Causing Land Conversion Source: analysis results, 2015

Based on the flow picture of the establishment of causal factors of land use change above, there are four factors causing formed of nine variables that influence in Manggala Sub-district. These factors among others: the lack of planning and law enforcement related to spatial planning; high demand for housing; the low price of open land; the uneven and partial of infrastructure's supply. Here below for more details about the establishment of the factors:

1. The lack of planning and law enforcement related to spatial planning

The policies referring Manggala Sub-district into integrated residential area without revealing aspects of the disaster caused an uncontrolled growth of settlements. So, there are so many conversion of catchment areas and fields into residential areas. It also sparked many home or housing development interventions to 
the government, thus undermining the rule of law, especially regarding environmental rules and licensing. Not only weakening law enforcement, public awareness / developer is getting low due legal awareness shown by the number of unlicensed buildings built in Manggala Sub-district in 2014 (70 cases). It also represents the lack of control by the government in law enforcement and encourage the decline of water catchment areas, as well as urging the region hydrological systems (drainage and river) resulting in increased risk of flooding in Manggala Sub-district, Makassar.

2. The high demand of housing

High population growth is closely correlated with the demand for residential land. In addition, the income level of the population is also rising influence of the increased demand, because the conditions of economic region tend to be unstable. However, the level of incomes of the population in Manggala belonging to medium level, caused the limited funds in the construction of self-help housing units. Therefore, people get around by buying land at low prices, such as wetlands, rice fields or gardens. These conditions will increasingly lead to the conversion of land, besides the natural conditions due to the growth of the construction. Large demand for housing would trigger to use of large-scale lands for houses which can be seen at Figure 7. Those were correlated to the increasing in building density which impact to the decrease in land infiltration, thereby increasing the risk of flood in Manggala Sub-District.

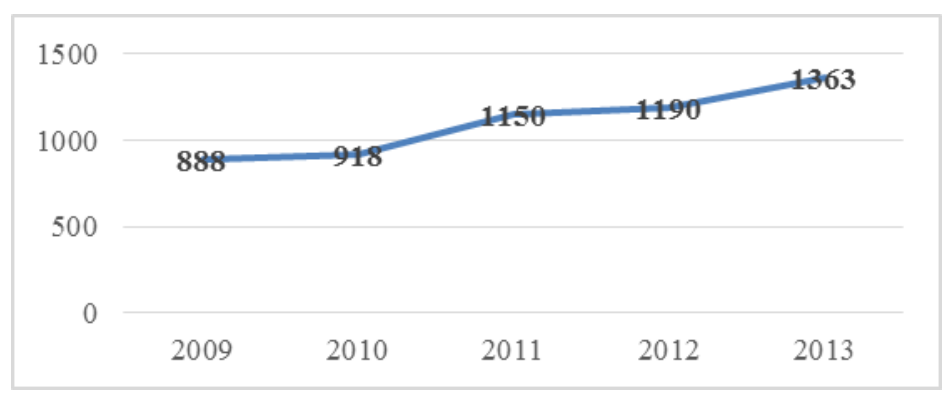

Figure 7. Publishing Rate of Building Permit in Manggala Sub-District. Source: Makassar in Figure, 2014

3. The low price of open land

The land price in the Manggala Sub-district is lower than the majority of land in the downtown area, especially on open land in the lowlands. The low price of land caused many speculators and land mafia, which led to the occupation of a large area for the benefit of housing construction by the community and society and developers. Non-building land is mostly located in the catchment area, so give an impact on the increased risk of flooding in the region. This is also compounded by the flood events that have occurred, causing the flooding affected many rice fields and become unproductive (Figure 8), so there are some farmers who sell their land to other communities or developers for housing construction. 
Land using in the catchment area resulted in a decrease in the extent of the area which may increase the frequency of flooding in Manggala Sub-district.

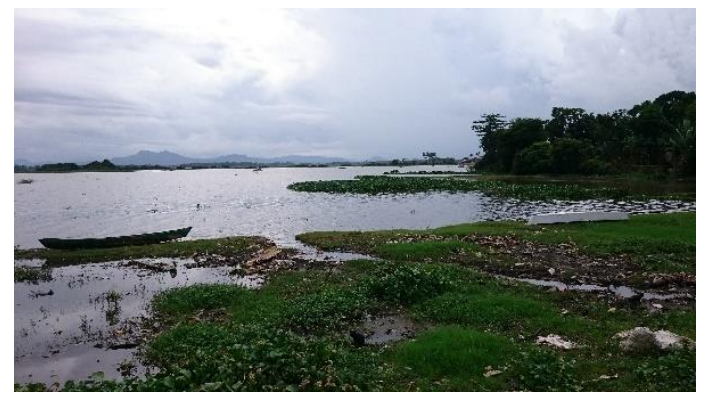

Figure 8. Flood Affected Rice Fields in the Tamangapa Village Source: field survey, 2014

4. The uneven and partial of infrastructure's supply

Supply of basic infrastructure for the development has not been evenly distributed in Manggala Sub-district, because most of the region served all types of basic infrastructure is only in the western region of the Manggala Sub-district and the eastern region is still not provided thoroughly. Generally, types of basic infrastructure which has been provided are roads, electricity and clean water. However, drainage infrastructure, sanitation, and so on are still not uneven and inadequate, but the land conversion in the region still occur. Therefore, these conditions pose risk of a negative impact especially increasing risk of flooding due to the unavailability of adequate drainage system, or developed drainage system was not connected to the drainage system of the city (Figure 9).

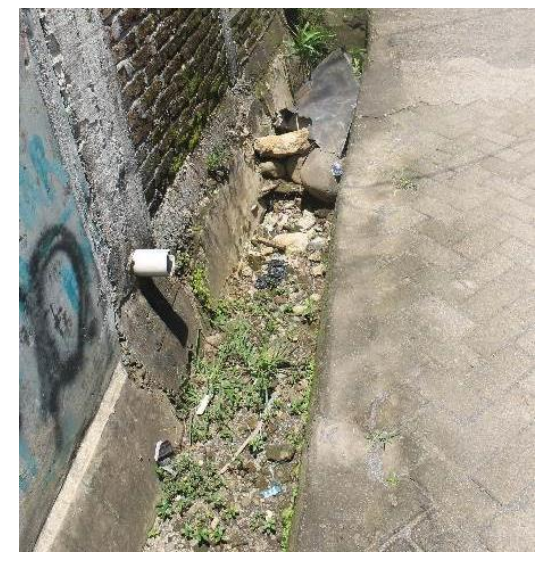

Figure 9. Example of Inadequate Drainage Condition in the

Settlement Area Source: field survey, 2014 


\section{CONCLUSIONS}

From content analysis, It can be determined the factors that cause land conversion, which trigger the increased risk of flooding in Manggala Sub-District. Those based on the understanding and experience of the stakeholders on the condition of land conversion in Manggala Sub-District, Makassar. Moreover, it reflects comprehensively from various perspectives (government, private sector and civil society). The factors consist of:

1. The lack of planning and law enforcement related to spatial planning, particularly against to the context of flooding prone areas in Makassar, thereby triggering many infringements use of lands that encourage the decline of water catchment areas, as well as urging the region hydrological systems.

2. The high demand for housing of middle class society in Manggala Sub-District that lead to increasing building density which impact to land infiltration.

3. The low price of open land in Manggala Sub-district which impact of the decline water catchment areas.

4. The uneven and partial of infrastructure's supply, especially the supply of flood control infrastructure such inadequate drainage conditions throughout Manggala Sub-district which increased the risk of flooding.

Although these factors were not the direct cause of the increased risk of flooding, but the increased of land conversions must be controlled in Manggala SubDistrict, as precautions against greater risk of flooding. Moreover, the use of content analysis in this study facilitate researchers in exploring the empirical conditions of a region deeply and comprehensively. It can help find the inferences related to phenomena, especially the problems that occurred in the study area. However, it required an accuracy of researchers to find the inference that is replicable so that no double interpretation by the readers.

\section{REFERENCES}

BPBD Kota Makassar (2014), Rencana Kontijensi Bencana Banjir Kota Makassar, BPBD Kota Makassar, Makassar.

BPS Kota Makassar (2007-2014), Makassar in Figure, BPS Kota Makassar, Makassar.

BPS Kota Makassar (2013-2014), Manggala Sub-District in Figure. BPS Kota Makassar, Makassar.

DTRB Kota Makassar (2012), Laporan Penyusunan Analisis Data dan Informasi Kawasan Banjir Pada Kawasan Perumahan di Kota Makassar, DTRB Kota Makassar, Makassar.

Dinas Tata Ruang dan Permukiman Propinsi Sulawesi Selatan (2011), Program Penanggulangan Banjir Wilayah Metropolitan Mamminsata, Dinas Tata Ruang dan Permukiman Sulsel, Makassar. 
Harjadi, et al. (2007), Pengenalan Karakteristik Bencana dan Upaya Mitigasinya di Indonesia, Bakornas PB, Jakarta.

Krippendorff, K. (1993), Analisis Isi Pengantar Teori dan Metodologi, Raja Grafindo Persada, Jakarta.

Krippendorff, K. (2004), Content Analysis: An Introductions to its Methodology (Second Edition), Sage Publication, California.

Rusbiantoro, D. (2008), Global Warming For Beginner: Pengantar Komprehensif Tentang Pemanasan Global, Andi Publisher, Yogyakarta. 